\title{
Linking biological toxicity and the spectral characteristics of contamination in seriously polluted urban rivers
}

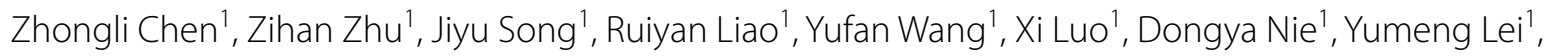
Ying Shao ${ }^{1 *} \mathbb{D}$ and Wei Yang ${ }^{2,3}$

\begin{abstract}
Background: Urban river pollution risks to environments and human health are emerging as a serious concern worldwide. With the aim to achieve the health of urban river ecosystem, numerous monitoring programs have been implemented to investigate the spectral characteristics of contamination. While due to the complexity of aquatic pollutants, the linkages between harmful effects and the spectral characteristics of contamination are still a major challenge for capturing main threats to urban aquatic environments. To establish these linkages, surface water (SW), sediment pore water (SDPW), and riparian soil pore water (SPW) were collected from five sites of the seriously polluted Qingshui Stream, China. The water-dissolved organic carbon (DOC), total nitrogen (TN), total phosphate (TP), fluorescence excitation-emission matrix, and specific ultraviolet absorbance were applied to analyze the spectral characteristics of urban river contamination. The Photobacterium phosphorem 502 was used to test the acute toxicity of the samples. Finally, the correlations between acute toxicity and concentrations of DOC, TN, TP, and the spectral characteristics were explored.
\end{abstract}

Results: The concentrations of DOC, TN, and TP in various samples amounted from $11.41 \pm 2.31$ to $3844.67 \pm 87.80 \mathrm{mg} / \mathrm{L}$, from $1.96 \pm 0.06$ to $906.23 \pm 26.01 \mathrm{mg} / \mathrm{L}$ and from $0.06 \pm 0.01$ to $101.00 \pm 8.29 \mathrm{mg} / \mathrm{L}$, respectively. The florescence index (FI) amounted from 1.54 to 3.14, the biological index (BIX) were between 0.94 and 1.57. The distribution patterns of specific ultraviolet absorbance at $254 \mathrm{~nm}\left(\mathrm{SUVA}_{254}\right)$ showed that the highest aromaticity and hydrophobicity were found in SDPW and the lowest ones were in SW. All samples showed significantly inhibition on luminescent bacteria. Particularly, the highest acute toxicity was found in site 1 with an $\mathrm{EC}_{50}$ value of 6.023-fold dilution for the raw SDPW sample. In addition, the highest fluorescence intensity was also observed from SDPW of site 1.

Conclusions: Tryptophan-like and protein-like substances could be important DOC fractions contributing remarkably to the acute toxicity in the seriously polluted river. In addition, the significant reduction on acute toxicity was found with the treatment of surface water flow constructed wetland, revealing that constructed wetland could be an effective approach for toxicant degradation. These observations are useful for water treatments, and meaningful for urban sustainable development.

Keywords: Urban stream, Three-dimensional fluorescence spectrum (EEMs), UV-Vis spectrum, Acute toxicity

\footnotetext{
*Correspondence: ying.shao0926@outlook.com

1 Key Laboratory of the Three Gorges Reservoir Eco-environment,

Ministry of Education, Chongqing University, Chongqing 400045, People's

Republic of China

Full list of author information is available at the end of the article
} 


\section{Background}

Urban river pollution poses risks to ecosystems and human health, which is emerging as a significant concern for urban sustainable development worldwide [1]. To ensure effective protections for aquatic ecosystems, the United Nations Development Program (UNDP) launched a strategy to improve the sustainability of water sanitation, of which protecting and restoring waterrelated ecosystems are essential [2]. While as required by the "Sustainable cities and communities", two-thirds of global population (6.5 billion people) will live in cities by 2050 , which will induce extensive widespread anthropogenic activities [3]. With these enormous increases of anthropogenic activities, overload pollutants deriving from industrial, agricultural, and household sewage will continuously emit into urban rivers, resulting in serious pollution for urbanized watersheds [4, 5]. For instance, China, as one of the fastest countries in the progress of urbanization in the 21 st century, more than $80 \%$ of China's urban rivers have been contaminated, most of which are seriously polluted, namely, become black-odor waters [6].

The black-odor water is usually associated with low amount of dissolved oxygen and negative redox potentials, which results in dark or grey color in waters. The black-odor water could seriously endanger the ecological functions of urban, and finally impacts on urban residents' health [7-10]. In China, a total of 1861 water bodies were labeled as black-odor water by the end of 2017, which led to damages on urban ecological functions and even on the residents' physical and mental health [11]. Thus, the black-odor water has been recognized as one of the most challenge for publics, government as well as academics [7].

The black-odor water is caused by excessive pollutants, which can induce imbalance of oxygen supply and consumption in aquatic systems [7]. These pollutants usually contain large volumes of organic matter, nitrogen, and phosphorus, which are important nutrients for microorganisms. On the contrary, the features of microorganisms (e.g., the growth condition of anaerobic or aerobic) affect the degradation of pollutants, which simultaneously influence the balance of oxygen supply and consumption in the aquatic environment [12]. Thus, the black-odor water quality assessment is typically based on the content of nutrients such as carbon, nitrogen, and phosphorus in the aquatic system. Dissolved organic carbon (DOC), as one of the most important carbon-containing nutrients, has been frequently used to evaluate the content of bioavailable carbon in waters [13]. Nitrogen and phosphorus are also the critical nutrients for biota, which are normally assessed by the total nitrogen (TN) volume and total phosphorus (TP) volume. In addition, the source, composition, hydrophilicity, and hydrophobicity of nutrients also play vita roles during microorganism metabolic process, and they hence are widely determined by the florescence index (FI), the biological index (BIX), fluorescence excitation-emission matrix (EEMs), the humification index (HIX), and specific ultraviolet absorbance at $254 \mathrm{~nm}\left(\mathrm{SUVA}_{254}\right)$ [14]. While due to the complexity of aquatic systems, safety/harmfulness assessment with solo use spectral characteristics mentioned above is inadequate. In considering that the objective of water quality assessment is to evaluate the safety/harmfulness of water bodies, various bioassays such as zebrafish embryo assay, alga growth inhibition assay, cell-based toxicity assays are frequently applied [15]. However, the linkages between harmful effects and spectral characteristics are still a major challenge for capturing main threats to aquatic environments [16].

To establish the linkages, the Qingshui Stream in the urban area of Chongqing was selected in the current study, since it is one of the listed black-odor water in China which affects 0.3 million residents' production and lives [17]. The surface water (SW) samples, sediment pore water (SDPW) samples, and the riparian soil pore water (SPW) samples were collected to measure the concentrations of DOC, TN, and TP. To identify the source and the compositions of DOC in the Qingshui Stream, the spectral characteristics of DOC were measured by fluorescence EEMs and SUVA [14]. The FI, HIX, BIX, and SUVA $_{254}$ were calculated based on the corresponding spectral data. The luminescent bacteria 502 which were reported to be an ideal model for acute toxicity investigation, and closely resemble the enzyme activity levels of the current population [18], were applied to test the acute toxicity of black-odor water in the current study. Finally, correlations between acute toxicity and water spectral characteristics, i.e., amounts of DOC, TN, and TP, and spectral characteristics of FI, HIX, BIX, and $\mathrm{SUVA}_{254}$, were analyzed to establish the linkages.

\section{Methods}

Study area

The Qingshui Stream is located in the Shapingba district of Chongqing, China (Fig. 1). The stream origins from the Gele mountain with a length of $15.88 \mathrm{~km}$, and is a branch of the Jialing River (one of the largest tributary in the upper stream of the Yangtze River). The watershed area of the Qingshui Stream is $35.54 \mathrm{~km}^{2}$, of which $21 \mathrm{~km}^{2}$ is located in the urban area. Therefore, it is a typical urban river in the southwest of China, which has been seriously polluted with urbanization process. The main sources of pollutants in Qingshui Stream are sewage discharge, agriculture non-point source pollution, wastewater from livestock breeding, and industrial wastewater. This area 


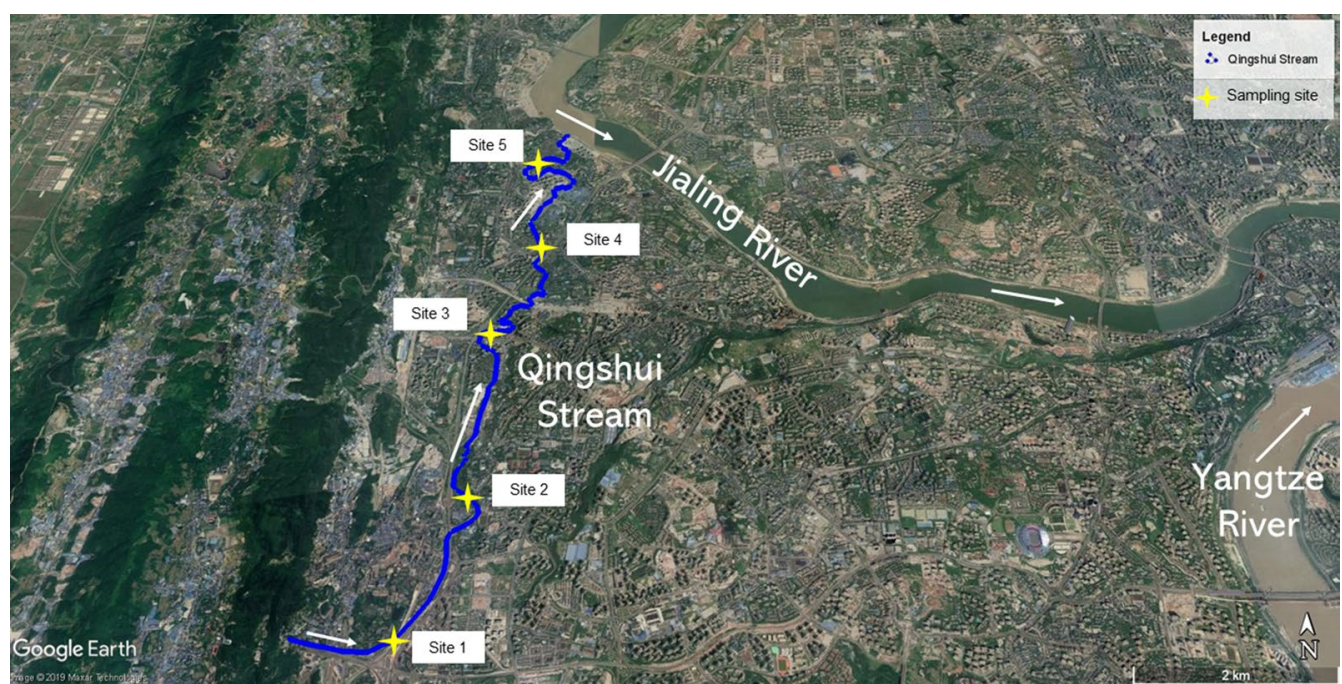

Fig. 1 Location and sampling sites distribution along the Qingshui Stream of Chongqing, China

has a mild, subtropical climate with a mean annual temperature of $18.3^{\circ} \mathrm{C}$ and a mean annual precipitation of $1082.9 \mathrm{~mm}$, of which $78 \%$ falls in wet periods. Five sampling sites that distributed from the upper stream (site 1) to downstream (site 5) were set up, as shown in Fig. 1. A surface water flow constructed wetland with an area of $14.63 \times 10^{4} \mathrm{~m}^{2}$ has been established between site 1 and 2 , which the river water treatment scale is up to 37000 $\mathrm{t} / \mathrm{d}$. The stream water flows through the constructed wetland. The stream water, sediment, and riparian soil were sampled at each site with three replicates. The samples were transported to the laboratory, of which the water and sediment were stored at $-20{ }^{\circ} \mathrm{C}$ refrigerator (DW86L338, Haier, China) prior to use. Analyzed was done after pre-treatment with each sample.

\section{Materials}

Luminescent bacteria 502 (Photobacterium phosphoreum) toxicity test Kit were percharged from Huaju Scientific Instruments Co. Ltd (Shenzhen, China). Sulfuric acid, nitric acid, perchloric acid, sodium hydroxide, potassium peroxodisulfate, ascorbic acid, ammonium molybdate heptahydrate, antimony potassium tartrate, monopotassium phosphate, phenolphthalein, and ethanol were obtained from Kelong Chemical Industry Co. Ltd (Chengdu, China), the purity of ethanol is $95 \%$, and the others are with analytically pure.

\section{Sample preparation}

Surface water samples of stream water were filtrated via $0.45 \mu \mathrm{m}$ PES syringe filter (Jinteng, Tianjin, China) and were stored at $4{ }^{\circ} \mathrm{C}$ in glass vials with Teflon-line caps. To prepare the pore water from sediments and riparian soil, sediment and riparian soil samples were centrifuged via $6000 \mathrm{rpm}$ for $10 \mathrm{~min}$ (TG-16, Sichuan Shuke, China) [19]. The supernate was filtrated via $0.45 \mu \mathrm{m}$ PES syringe filter (Jinteng, Tianjin, China), and were stored at $4{ }^{\circ} \mathrm{C}$ prior to use. The procedure of SPW preparation was modified according to the method of Thibault and Sheppard [20]. 25 g riparian soil from each sample were transported into the centrifuge tube with $20 \mathrm{~mL}$ deionized water (Molecular, 1810A, Shanghai, China), and the following pretreat process was the same as sediment pore water preparation.

\section{Measurement of physico-chemical properties}

The total phosphorus (TP) concentrations of raw SW, SDPW, and SPW were measured by ammonium molybdate spectrophotometric method [21]. The total nitrogen (TN) concentrations were measured by ultraviolet spectrophotometry with basic potassium persulfate [22]. The concentrations of DOC were determined via high-temperature combustion and oxidation in a TOC analyzer (Shimadzu TOC-L, Japan) [19].

\section{Measurement of the spectral characteristics}

The spectral characteristics of the samples were determined by the FI, HIX, BIX, and $\mathrm{SUVA}_{254}$ and the three-dimensional excitation-emission matrix of the substances. The three replicates of each sample were mixed before the spectral characteristics measurement. The $\mathrm{SUVA}_{254}$ was calculated by the UV absorbance at $254 \mathrm{~nm}$ normalized by the DOC concentration (ultraviolet spectrophotometer, Beijing Puxi-T6, Beijing, China) [13]. The FI, HIX, BIX, and fluorescence EEMs were scanned by a luminescence spectrometer (FL 
Spectrophotometer, F-7000, Hitachi High-Technologies Global, Japan) with the emission wavelengths stepping from $250 \mathrm{~nm}$ to $620 \mathrm{~nm}$ at $5 \mathrm{~nm}$ increment and the excitation wavelengths stepping from $230 \mathrm{~nm}$ to $450 \mathrm{~nm}$ at $5 \mathrm{~nm}$. The scanning speed was $12,000 \mathrm{~nm} / \mathrm{min}$, and both slit widths were set to $5 \mathrm{~nm}$. The FI is given as the ratio of fluorescence intensities at 370:450 and 370:500 (excitation: emission wavelengths in $\mathrm{nm}$ ). The HIX was estimated using the ratio of the areas under the emission spectra over $435-480 \mathrm{~nm}$ to $300-345 \mathrm{~nm}$ at an excitation wavelength of $255 \mathrm{~nm}$ [13]. The BIX was calculated by the ratio of excitation wavelength of $310 \mathrm{~nm}$ at emission wavelength of $380 \mathrm{~nm}$ and $430 \mathrm{~nm}$ [23]. The proteinlike compounds and humic-like substances in DOC were identified by the fluorescence EEMs.

\section{The luminescent bacteria toxicity test}

For the acute toxicity test, luminescent bacteria 502 freeze-dried particles as pellets in glass bottles were removed from $-20{ }^{\circ} \mathrm{C}$ storage, and then, the recovery medium was added for rehydration at $20{ }^{\circ} \mathrm{C}$ for $15 \mathrm{~min}$. The standard methods for culture medium preparation and bacteria 502 incubation are referenced to the previous article [24]. Toxicity of SDPW samples was evaluated by measuring the inhibition of bioluminescence of luminescent bacterial strains. The luminescence inhibition assay was performed in test tubes using a hand-held biotoxicity detector (BM-60, Huaju Scientific Instruments Co. Ltd, Shenzhen, China) according to the manufacturer's protocol luminometer (Huaju Scientific Instruments Co. Ltd, Shenzhen, China). For each test, 10 test tubes were prepared, eight for different water samples, one for negative control (recovery liquid) and one for positive control $\left(\mathrm{ZnSO}_{4} \cdot 7 \mathrm{H}_{2} \mathrm{O}\right.$ at $\left.5 \mathrm{mg} / \mathrm{L}\right)$. Sample or control liquid $(1 \mathrm{~mL})$ was added after pretreated with osmotic pressure regulator, and the bacterial suspension $(50 \mu \mathrm{L})$ was added with $10 \mathrm{~s}$ intervals. After 15 min exposure of the bacteria to the sample at $20^{\circ} \mathrm{C}$, the relative light unit (LU) of luminescent bacterium 502 was measured. The acute toxicity of the sample on strain 502 was expressed as an inhibition ratio, calculated by the following formulation [25]:

$$
X \%=\left(1-\mathrm{LU}-\mathrm{LU}_{0}\right) \times 100 \%
$$

where $L_{0}$ was the RLU of strain 502 exposed to the negative control and LU was the RLU of the samples. For raw surface sample from site $1, \mathrm{EC}_{50}$ values which are the concentration of toxicant that produces $50 \%$ inhibition of light emission from a specific strain of bioluminescent bacteria were calculated to express the toxicity of water samples. Each test was carried out with three independent replicates.

\section{Statistical analysis}

All spreadsheet calculations were performed using Microsoft Excel ${ }^{\mathrm{TM}}$ 2016, Origin Pro 8.5.1 (Origin Lab Corporation). The information on fluorescence EEMs was also performed by Origin. All data sets of different treatments were tested for statistically significant differences using one-way analysis of variance. Tukey's test was used to identify significant differences between treatments and controls at $P<0.05$. Pearson test was used for correlation analysis at $P<0.05$.

\section{Results}

Physico-chemical parameters of aquatic environment DOC concentrations of SW, SDPW, and SPW along stream longitudinal gradients are shown in Fig. 2a. We found that DOC concentrations in SW amounting from $51.15 \pm 0.38$ to $55.54 \pm 5.77 \mathrm{mg} / \mathrm{L}$, which were higher than that in SDPW ranging from $25.82 \pm 0.97$ to $42.54 \pm 1.06 \mathrm{mg} / \mathrm{L}$ ) along the stream longitudinal gradients with an exception in site $1(3844.67 \pm 87.80 \mathrm{mg} / \mathrm{L})$. DOC concentrations in SPW ranged from $11.41 \pm 2.31$ to $347.73 \pm 4.75 \mathrm{mg} / \mathrm{L}$. The TN concentrations of SW (from $11.85 \pm 0.53$ to $19.08 \pm 2.65 \mathrm{mg} / \mathrm{L}$ ) and SDPW (from $35.93 \pm 2.88$ to $906.23 \pm 26.01 \mathrm{mg} / \mathrm{L}$ ) fluctuated along the
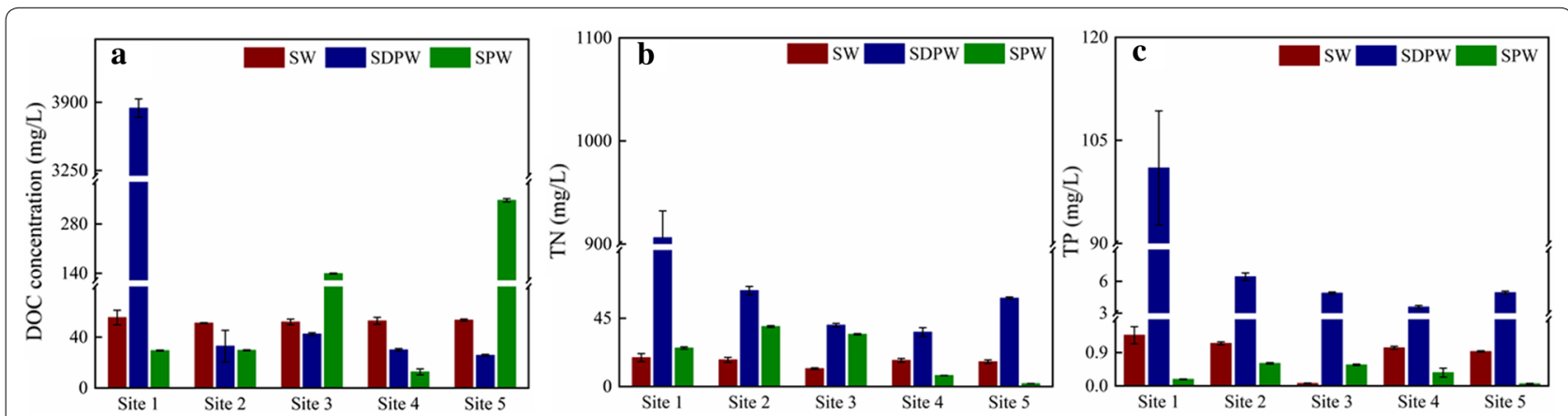

Fig. 2 Concentrations of dissolved organic carbon (DOC) (a), total nitrogen (TN) (b), and total phosphorus (TP) (c) in surface water (SW), sediment pore water (SDPW), and soil pore water (SPW) along the Qingshui Stream longitudinal gradients 
stream longitudinal gradients, while a decrease trend on $\mathrm{TN}$ was found in SPW $(39.60 \pm 0.6$ to $1.96 \pm 0.06 \mathrm{mg} / \mathrm{L})$, with site 1 as the exception (Fig. 2b). Regarding the concentration of TP (Fig. 2c), the TP concentration in SDPW (from $3.59 \pm 0.14$ to $101.00 \pm 8.29 \mathrm{mg} / \mathrm{L}$ ) was higher than those in SW (from $0.07 \pm 0.01$ to $1.37 \pm 0.23 \mathrm{mg} / \mathrm{L}$ ) and SPW $(0.06 \pm 0.01$ to $0.61 \pm 0.02 \mathrm{mg} / \mathrm{L})$.

\section{Spectral characteristics and source of DOC}

The results of spectral properties are shown in Fig. 3. The highest FI were found in the SW, with the amounts ranging from 2.90 to 3.14 for $\mathrm{SW}$, from 2.42 to 2.73 for SPW, and from 1.54 to 2.68 for SDPW, respectively. We found that the BIX fluctuated slightly along with the stream longitudinal gradients, amounting from 0.94 to 1.46 for SPW, from 1.08 to 1.13 for SW, and from 0.97 to 1.57 for SDPW, respectively. Regarding the HIX, the sequence was $\mathrm{SPW}>\mathrm{SW}>\mathrm{SDPW}$, with an exception in site 5. Compared to SPW and SDPW, the HIX in SDPW was extremely low at sites of $1-3$, with the amounts ranging from 0.06 to 0.23 . The $\mathrm{SUVA}_{254}$ in $\mathrm{SW}$ was slightly fluctuating from 0.36 to $0.42 \mathrm{~m}^{-1} /(\mathrm{mg} / \mathrm{L})$, while those in
SPW and SDPW were significantly higher than that in SW, with an exception in site 1 .

The EEMs results (Table 1) indicated that four fluorescence components were successfully extrapolated including tryptophan-like substances $(\mathrm{C} 1)$, protein-like organic substances (C2), humic-like organic substances (C3), and fulvic acid-like organic substances (C4). We found that protein-like compounds were dominated in all water samples, tryptophan-like compounds were found at SDPW samples and SW of site 5, while humic-like and fulvic acid-like compounds were mainly found at SW and SPW, respectively. Moreover, the highest fluorescence intensity was observed in SDPW of site 1, with the values up to about 10,000 (Fig. 5).

\section{Luminescent bacteria toxicity of sediment pore water}

In the current study, the DOC, TN, and TP concentrations in SDPW were higher than those in SPW and SW; therefore, the luminescent bacteria acute toxicity test was performed in SDPW samples. The results are shown in Fig. 4a. It was found that samples from site 1 and site 3 induced significantly inhibition
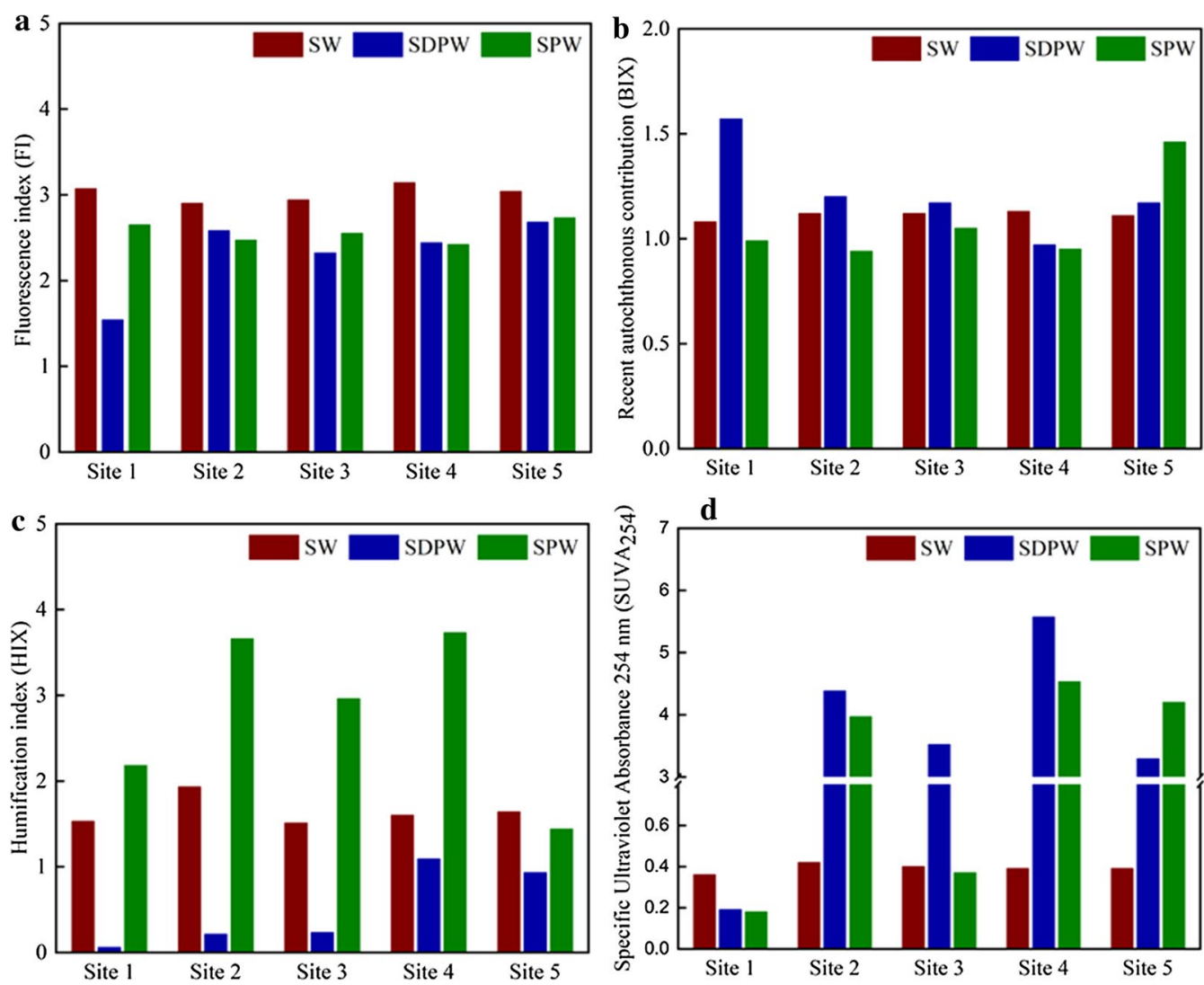

Fig. 3 Spectral characteristics of a florescence index (FI), b biological index (BIX), c humification index (HIX), and $\mathbf{d}$ specific ultraviolet absorbance at $254 \mathrm{~nm}\left(\mathrm{SUVA}_{254}\right)$ for the surface water (SW), sediment pore water (SDPW), and soil pore water (SPW) along the Qingshui Stream longitudinal gradients 
Table 1 Four fluorescence components decomposed from surface water (SW), sediment pore water (SDPW), and soil pore water (SPW) of the Qingshui Stream of Chongqing, China

\begin{tabular}{llll}
\hline Samples & Ex/Em/(nm) & Component & $\begin{array}{l}\text { Wavelength } \\
\text { in the references/(Ex/ } \\
\text { Em/nm) }\end{array}$ \\
\hline SDPW of site 1-5; SW of site 5 & $225 / 325,<225 / 320,<250 / 350$ & C1: Tryptophan-like & $<240 / 330-370[26,27]$ \\
SDPW/SPW/SW of site 1-5 & $275 / 300,275 / 340,280 / 320,280 / 325,280 / 330$, & C2: Protein-like & $240-280 / 300-350[28]$ \\
& $280 / 340,280 / 350$ & & $<250 / 370-430[26,27,29]$ \\
SW of site 1-4 & $200 / 380,<200 / 380,<225 / 380,240 / 400,240 / 390$ & C3: Humic-like (Ultraviolet A) & $<240-270 / 370-440[29]$ \\
SPW of site 2-5 & $250 / 375,250 / 380,245 / 400,250 / 400,270 / 370$, & C4: Fulvic acid-like & 240 \\
\hline
\end{tabular}
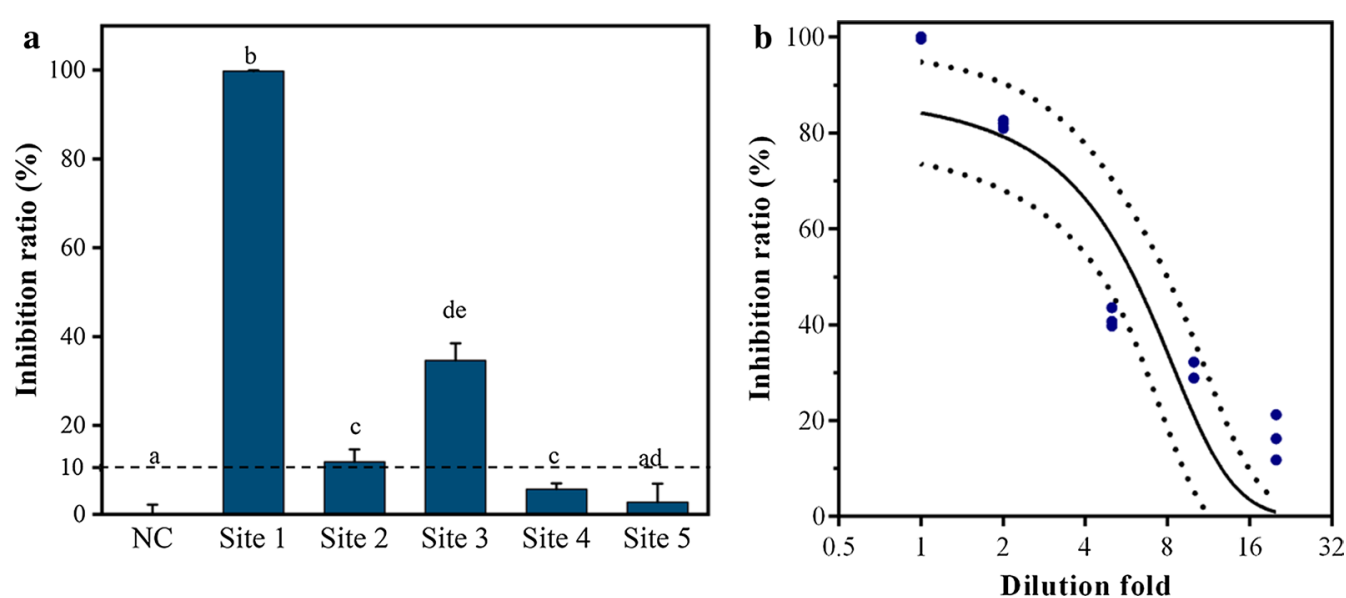

Fig. 4 Luminescent bacterial acute toxicity of sediment pore water. a Inhibition ratio of 5 raw sediment pore water (SDPW) samples on luminescent bacteria 502; b inhibition ratio of diluted SDPW sample from site 1 on luminescent bacteria 502. NC negative control. Data are given as means of 3 replicates \pm SD. Different letters on each column indicate significant differences at $P<0.05$, the regression curves (black lines) are shown with their 95\% confidence intervals (dashed lines), in which the top and bottom of the curve were set to 0\% and 100\%, respectively

$(2.71 \pm 4.12-99.75 \pm 0.19 \%)$ on luminescent bacteria 502 when compared to the negative control (NC) (Fig. 4a). Moreover, the inhibition ratio varied significantly between each site, with an exception for that between sites 2 and 4 . The highest inhibition ratio was observed on site 1 . Thus, further acute toxicity test was implemented for the dilution samples of site 1 , with the dilution factors of 2, 5, 10, and 20 (Fig. 4b). The $\mathrm{EC}_{50}$ value was 6.023 folds dilution of the raw SDPW sample at site 1.

\section{Correlation analysis}

The correlation between luminescent bacteria 502 acute toxicity and each physico-chemical characteristics was analyzed by Pearson correlation test for SDPWs (Fig. 6). The acute toxicity effects of SDPW were significantly correlated with their physico-chemical parameters, with significantly negative correlations being found for FI $(r=-0.980, P<0.01)$ and $\mathrm{SUVA}_{254}(r=-0.899, P<0.05)$, and positively correlations being observed from BIX $(r=0.907, P<0.05), \mathrm{TP}(r=0.952, P<0.05), \mathrm{TN}(r=0.948$, $P<0.05)$, and DOC $(r=0.952, P<0.05)$.

\section{Discussion}

DOC is a major concern in urban river pollution, which includes thousands of anthropogenic pollutants [30]. These increasing anthropogenic organic matters could arise the histological hazards to the fish and other aquatic organisms, including damages on their gills, thyroid, haematopoietic tissue, and peripheral blood cells in the water bodies [31]. These histological hazards could induce ecology risks in urban river and even influences on human health of residents. In the current study, DOC concentrations of SW samples in the Qingshui Stream $(51.15 \pm 0.38-55.54 \pm 5.77 \mathrm{mg} / \mathrm{L}$, Fig. 2a) were higher than that in the Three Gorges Reservoir of the Yangtze River with an average value of $11.9 \mathrm{mg} / \mathrm{L}$ [32] and rivers in USA $(1.0-42.1 \mathrm{mg} / \mathrm{L})[33,34]$. These phenomena may reveal a heavy pollution of carbon-containing compounds in the Qingshui Stream. Moreover, it is noticed 
that a relative high amount of DOC was observed in SPW of site 5 , which may be due to the hydrologic processes. As mentioned above, the riparian zone of downstream reaches of the Qingshui Stream is submerged by flooding of the Jialing River during summer season. In addition, the Qingshui Stream is located at the end of backwater of the Three Gorges Reservoir; thus, it is affected by the hydrological regulation of the Three Gorges Dam, i.e., winter flooding [35]. The submergence may usually result in accumulation of nutrients such as DOC in the SPW. The relative higher concentrations of TN and TP were detected in SDPW samples than those in SW samples along the whole stream reaches. The possible reason could be long-term accumulation of nutrients in sediments. It is known that sediments are usually both sink and source of nutrients, and hence, the concentration of nutrients in the SDPW normally higher than that in the SW. The current results give further evidence of that the long-term nutrients' accumulation phenomena in sediments along the whole Qingshui stream; thus, a great attention should be given [31].

The FI is always used to determine the source of DOC in various water samples. The FI value higher than 1.8 means that DOC consist of microbially derived substances, and the FI value lower than 1.3 suggests that DOC contain terrestrially derived substances [36]. Our results showed that besides site 1 SDPW sample $(\mathrm{FI}=1.54)$, all observed $\mathrm{FI}$ values were higher than 1.8 (Fig. 3a), implying that the source of DOC in most sampling sites is derived from extracellular release and leachate from bacteria and algae, rather than from terrestrial plant and soil organic matter [29, 37], whereas differences were found with that of the Ebinur Lake watershed, Amazon basin near Jurnena and the Hao River of China, in which the surface water DOC was predominantly terrigenous [34, 36, 38] Compared to these rivers, the physiological metabolic processes of microorganism and algae in black-odor waters may be strongly influenced by the overload pollutants, and thus, more autogenous DOC was released into water bodies.

BIX is utilized for charactering of autochthonous biological activity in water samples [23]. The BIX value higher than 0.8 could be considered, as that autochthonous compounds are majority contribution of DOC [23]. In the current study, the BIX values were between 0.94 and 1.57 (Fig. 3b), indicated that the DOC may be mainly contributed by hydrotropic substances. HIX is frequently selected to estimate the degree of maturation of DOC [23]. All the HIX values were lower than 4 in Fig. 3c, revealed that the weak extent of humification and the DOC fractions contain less humic substances $[37,39]$. In addition, we found that HIX of SDPW were significantly lower than that of SW and SPW in the upper and middle reaches of the stream, indicating the rare input of terrigenous DOC in SDPW samples, while high amounts of DOC were detected in SDPW of those areas, implying that the DOC was mainly autogenous in the Qingshui Stream. It is known that the value of $\mathrm{SUVA}_{254}$ is higher than 4 referring to hydrophobic aromatic compounds, and $\mathrm{SUVA}_{254}$ is lower than 3 indicating hydrophilic matters [14]. In the current study, the $\mathrm{SUVA}_{254}$ of SW was significantly lower than those of SDPW and SPW with site 1 as the exception (Fig. 3d). These results were significantly lower than in Arctic headwater streams [1.31$6.87 / \mathrm{m}(\mathrm{mg} / \mathrm{L})]$ [40]. Thus, hydrophilic materials were the major DOC compounds in the surface water, while hydrophobic aromatic compounds were mainly distributed in both sediment and riparian soil pore water.

All the SDPW samples showed significantly acute toxicity effects (Fig. 4); simultaneously, the results of EEMs further confirmed that the DOC compounds in SDPW were mainly tryptophan-like and protein-like substances (Table 1, Fig. 5), revealing that these substances could contribute to acute toxicity in the seriously polluted rivers [41]. The strongest acute toxic effect was found at site 1 , where the highest intensities of fluorescence peaks were also presented, which further confirmed that tryptophan-like and protein-like compounds may induce acute toxicity on the luminescent bacteria. These results are in consistence with the previous study. We found that the inhibition effects on luminescent bacteria 502 were also observed from the diluted SDPW samples (Fig. 4b), indicating the sensitivity of luminescent bacteria 502 for the environmental sample acute toxicity evaluation. $\mathrm{He}$ and his colleagues also reported that luminescent bacteria are more sensitive than zebrafish to inspect biotoxicity [6], revealing that luminescent bacteria acute toxicity test can be an effective bioassay in black-odor water quality assessment. The acute toxicity of SDPW sample at site 2 was significantly lower than that at site 1 , the possible reason could be the constructed wetland which is located between sites 1 and 2 . These phenomena were proved by a mechanism study, in which the constructed wetland, on one hand, can trap and remove pollutants by the processes of sorption, photo-oxidation, and volatilization; on the other hand, biota and microorganisms in the constructed wetland can uptake and degrade contaminations by biological means [42].

Significant linkages between acute toxicity effects and physico-chemical parameters were obtained (Fig. 6). The SDPW sample on site 1 induced the highest acute toxic effect (Fig. 4); simultaneously, it exhibited the highest concentrations of DOC, TN, and TP (Fig. 2). These observations suggested that the DOC, TN, and TP could be mainly contributions for the acute toxic effect on luminescent bacteria 502 . These findings further confirmed by 

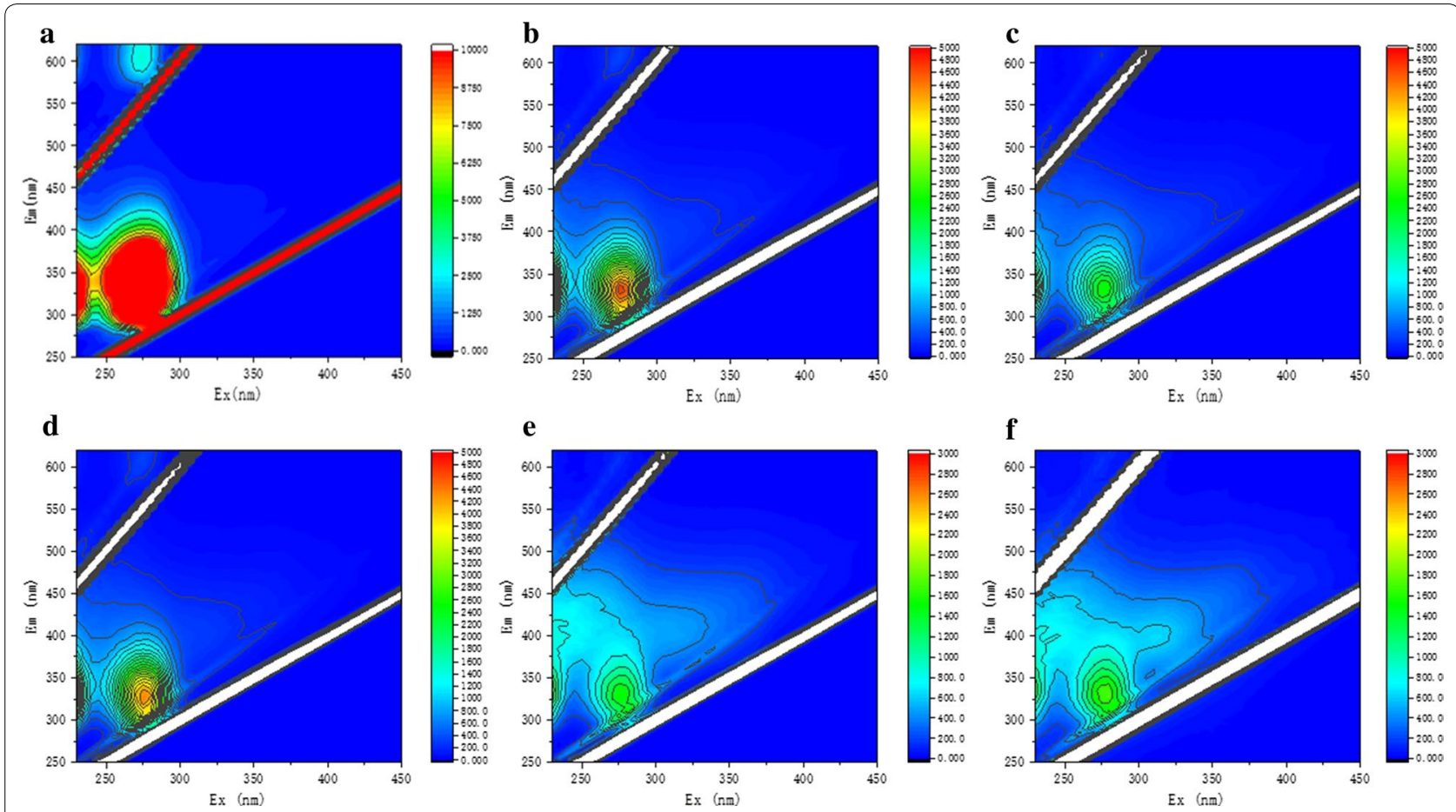

Fig. 5 Fluorescence characterization of dissolved organic carbon (DOC) composition in sediment pore water (SDPW) of the Qingshui Stream. a site $1, \mathbf{b}$ site 2, c site 3, d site 4, e site 5, and $\mathbf{f}$ site 6 . Fluorescence intensities are in Raman units normalized to DOC concentration

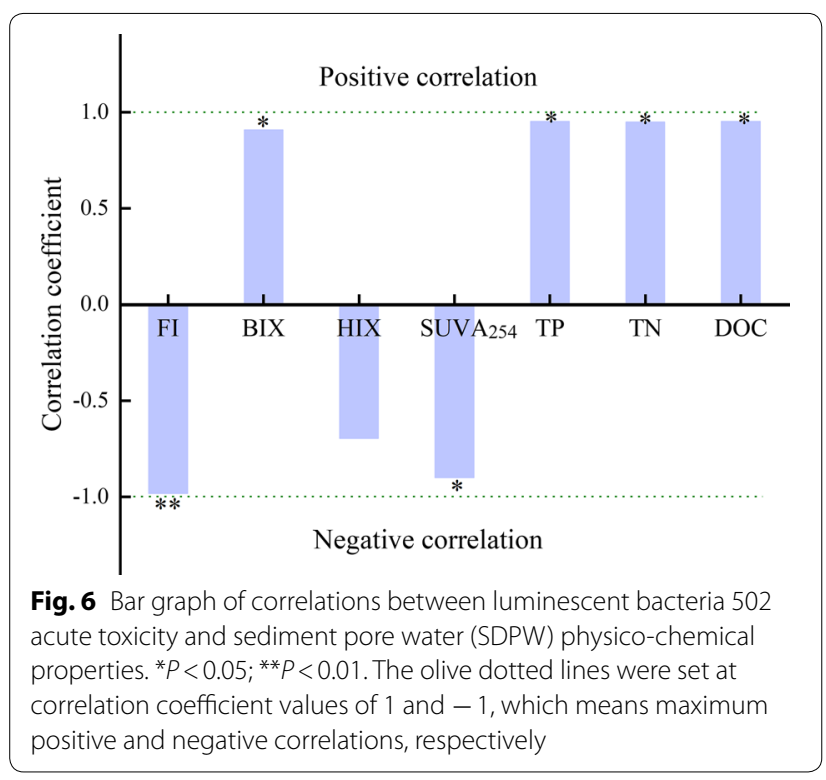

the correlation analysis, which the significantly positive correlation was found between acute toxicity and DOC, TN, and TP (Fig. 6). Previous studies also proved that polycyclic aromatic hydrocarbons (PAHs), as one kind of DOC with mutagenic and/or carcinogenic properties, have been detected frequently in urban waters [43]. PAHs and their photo-irradiation products can induce acute toxicity on luminescent bacterium [44]. Meanwhile, it was reported that PAHs could cause negative effects on aquatic organisms, which may raise the ecological risk on urban river ecosystems [45]. Phosphorous compounds such as organophosphorus pesticides induce toxic effects to luminescent bacterium even at very low concentrations, which is one of the major concerns for aquatic environmental risk assessment [46, 47], while BIX is also significantly positively correlated to acute toxicity [48], which is lack of concerns, and should be paid more attention in the future studies.

\section{Conclusions}

The highest acute toxicity was obtained in the SDPW of site 1, with the $\mathrm{EC}_{50}$ value up to 6.023 folds dilution of the raw SDPW. Meanwhile, EEMs showed that tryptophanlike and protein-like compounds were highest in the SDPW of site 1 . These findings indicate that tryptophanlike and protein-like substances could be important DOC fractions contributing remarkably to the acute toxicity in seriously polluted urban waters. In addition, the surface water flow constructed wetland exhibited significant reduction on acute toxic effect, which demonstrates that constructed wetland can be an effective approach for toxicant degradation. In considering of the requirements of systematically pollution treatment, further analysis 
on the seasonal dynamics of spectral characteristics and toxic effects is necessary. Our study could be applied to guild the seriously polluted water treatments, which is meaningful for urban sustainable development, in particular for sustainable water usage [49].

\section{Abbreviation}

UNDP: United Nations Development Program; DOC: dissolved organic carbon; TN: total nitrogen; TP: total phosphorus; Fl: florescence index; BIX: biological index; EEMs: fluorescence excitation-emission matrix; HIX: humification index; SUVA $_{254}$ : specific ultraviolet absorbance at $254 \mathrm{~nm}$; PAHs: polycyclic aromatic hydrocarbons; SW: surface water; SDPW: sediment pore water; SPW: riparian soil pore water; NC: negative control; RLU: relative light unit.

\section{Acknowledgements}

We would like to thanks urban and rural construction committee of Shapingba district, Chongqing, China for providing some background documents regarding Qingshui Stream.

\section{Authors' contributions}

YS performed the majority of experiments, data evaluations and was a major contributor in editing the manuscript; $\mathrm{ZLC}$ and $\mathrm{ZHZ}$ wrote the manuscript; YML, YFW, DYN, JYS, XL, and RYL contributed on field sampling and sample analysis; WY supported the data evaluations. All authors read and approved the final manuscript

\section{Funding}

This work was supported by the Fundamental Research Funds for the Central Universities (Nod. 2019CDXYCH0026 and 2019CDYGYB028) and the Vebture \& Innovation Support Program for Chongqing Overseas Returnees (No. cx2018069).

\section{Availability of data and materials}

The data sets used and/or analyzed during the current study are available from the corresponding author on reasonable request.

\section{Ethics approval and consent to participate}

Not applicable.

\section{Competing interests}

The authors declare that they have no competing interests.

\section{Consent for publication}

All authors agreed to publish the paper.

\begin{abstract}
Author details
1 Key Laboratory of the Three Gorges Reservoir Eco-environment, Ministry of Education, Chongqing University, Chongqing 400045, People's Republic of China. ${ }^{2}$ National Inland Waterway Regulation Engineering Research Center, Chongqing Jiaotong University, Chongaing 400074, People's Republic of China. ${ }^{3}$ Key Laboratory of Ministry of Education for Hydraulic and Water Transport Engineering, Chongqing Jiaotong University, Chongqing 400074, People's Republic of China.
\end{abstract}

Received: 22 July 2019 Accepted: 19 October 2019

Published online: 04 November 2019

\section{References}

1. Booth DB, Karr JR, Schauman S, Konrad CP, Morley SA, Larson MG, Burges SJ (2004) Riviving urban streams: land use, hydrology, biology, and human behavior. JAWRA 40:1351-1364

2. UNDP. Sustainable development goals. 2019. https://www.undp.org/ content/undp/en/home/sustainable-development-goals.html. Accessed 10 July 2019

3. WHO (2010) Bulletin of the World Health Organization. World Health Organization, Geneva, pp 241-320
4. Hughes RM, Dunham S, Maas-Hebner KG, Yeakley JA, Schreck C, Harte M, Molina N, Shock CC, Kaczynski VW, Schaeffer J (2014) A review of urban water body challenges and approaches: (1) rehabilitation and remediation. Fisheries. 39:18-29

5. Booth DB, Roy AH, Smith B, Capps KA (2016) Global perspectives on the urban stream syndrome. Freshw Sci 35:412-420

6. He DF, Chen RR, Zhu EH, Chen N, Yang B, Shi HH, Huang MS (2015) Toxicity bioassays for water from black-odor rivers in Wenzhou, China. Environ Sci Pollut Res 22:1731-1741

7. Cai W, Li Y, Wang C, Wang P, Wang L, Niu L, Zhang W (2019) Vertical distribution and assemblages of microbial communities and their potential effects on sulfur metabolism in a black-odor urban river. J Environ Manag 235:368-376

8. Güneş E, Talınılı I (2013) A site-specific index to control the total effect of point sources discharges and to achieve 'Good Chemical Status' in effluent dependent and effluent dominated water bodies: application on Ergene River basin. Water Resour Manag 27:221-237

9. Sanyal T, Kaviraj A, Saha S (2015) Deposition of chromium in aquatic ecosystem from effluents of handloom textile industries in Ranaghat-Fulia region of West Bengal, India. J Adv Res 6:995-1002

10. Dash P, Silwal S, Ikenga JO, Pinckney JL, Arslan Z, Lizotte RE (2015) Water quality of four major Lakes in Mississippi, USA: impacts on human and aquatic ecosystem health. Water 7:4999-5030

11. Wang W, Wang Y, Fan P, Chen L, Chai B, Zhao J, Lu Q (2019) Effect of calcium peroxide on the water quality and bacterium community of sediment in black-odor water. Environ Pollut 248:18-27

12. Schwarzenbach RP, Escher BI, Fenner K, Hofstetter TB, Johnson CA, von Gunten U, Wehrli B (2006) The challenge of micropollutants in aquatic systems. Science 313:1072-1077

13. Derrien M, Lee YK, Park J-E, Li P, Chen M, Lee SH, Lee SH, Lee J-B, Hur J (2017) Spectroscopic and molecular characterization of humic substances (HS) from soils and sediments in a watershed: comparative study of HS chemical fractions and the origins. Environ Sci Pollut Res 24:16933-16945

14. Tuhkanen T, Ignatev A (2019) Humic and fulvic compounds, in Encyclopedia of Analytical Science. In: Worsfold P, Poole C, Townshend A, Miró M, Eds. Academic Press, Oxford. pp 411-417

15. Neale PA, Munz NA, Aït-Aïssa S, Altenburger R, Brion F, Busch W, Escher Bl, Hilscherová K, Kienle C, Novák J, Seiler T-B, Shao Y, Stamm C, Hollender $J$ (2017) Integrating chemical analysis and bioanalysis to evaluate the contribution of wastewater effluent on the micropollutant burden in small streams. Sci Total Environ 576:785-795

16. Shao Y, Hollert H, Tarcai Z, Deutschmann B, Seiler T-B (2019) Integrating bioassays, chemical analysis and in silico techniques to identify genotoxicants in surface water. Sci Total Environ 650:3084-3092

17. Qing X, Ren Y, Lü Z, Wang X, Pang R, Deng R, Meng L, Ma H (2015) Characteristics of total nitrogen and total phosphorus pollution and eutrophication assessment of secondary river in urban Chongqing. Environ Sci 36:2446-2452

18. Yan XJ, Zhang L, Guo JM, Cao YD, Shang EX, Tang YP, Ding AW, Duan JA (2014) Processing of kansui roots stir-baked with vinegar reduces kansui-induced hepatocyte cytotoxicity by decreasing the contents of toxic terpenoids and regulating the cell apoptosis pathway. Molecules 19:7237-7254

19. Shao Y, Chen Z, Xiao H, Zhu Z, Li B (2019) Integrating environmental parameters and economic benefits to analyze the ecological agriculture (EA) application in the mountain rice paddy system of Chongqing, China. Environ Sci Eur 31(1):22

20. Trenfield MA, McDonald S, Kovacs K, Lesher EK, Pringle JM, Markich SJ, Ng JC, Noller B, Brown PL, van Dam RA (2011) Dissolved organic carbon reduces Uranium bioavailability and toxicity. 1. Characterization of an aquatic fulvic acid and its complexation with Uranium[VI]. Environ Sci Technol 45:3075-3081

21. National standards of the People's Republic of China (1989) Water qualityDetermination of total phosphorus-Ammonium molybdate spectrophotometric method. Ministry of Ecology and Environment, the People's Republic of China GB/T 11893-1989

22. National Environmental Protection standards of the People's Republic of China (2012) Water quality-Determination of total nitrogen-Alkaline potassium persulfate digestion UV spectrophotometric method. Ministry of Ecology and Environment, the People's Republic of China HJ 636-2012 
23. Huguet A, Vacher L, Relexans S, Saubusse S, Froidefond JM, Parlanti E (2009) Properties of fluorescent dissolved organic matter in the Gironde Estuary. Org Geochem 40:706-719

24. Shao Y, Wu LL, Gao HW, Wang F (2012) Effect of soluble sulfide on the activity of Luminescent bacteria. Molecules 17:6046-6055

25. Zhou X, Sang W, Liu S, Zhang Y, Ge H (2010) Modeling and prediction for the acute toxicity of pesticide mixtures to the freshwater luminescent bacterium Vibrio qinghaiensis sp.-Q67. J Environ Sci 22:433-440

26. Cory R, McKnight D (2005) Fluorescence spectroscopy reveals ubiquitous presence of oxidized and reduced quinones in dissolved organic matter. Envrion Sci Technol 39:8142-8149

27. Murphy K, Ruiz G, Dunsmuir W, Waite T (2006) Optimized parameters for fluorescence-based verification of ballast water exchange by ships. Environ Sci Technol 40:2357-2362

28. Stedmon C, Markager S (2005) Resolving the variability in dissolved organic matter fluorescence in a temperate estuary and its catchment using PARAFAC analysis. Limnol Oceanogr 50:686-697

29. Fellman JB, Hood E, Spencer RGM (2010) Fluorescence spectroscopy opens new windows into dissolved organic matter dynamics in freshwater ecosystems: A review. Limnol Oceanogr 55:2452-2462

30. Shao Y, Chen Z, Hollert H, Zhou S, Deutschmann B, Seiler T-B (2019) Toxicity of 10 organic micropollutants and their mixture: Implications for aquatic risk assessment. Sci Total Environ 666:1273-1282

31. Kitsiou D, Karydis M (2011) Coastal marine eutrophication assessment: a review on data analysis. Environ Int 37:778-801

32. Mao R, Chen H, Li S (2017) Phosphorus availability as a primary control of dissolved organic carbon biodegradation in the tributaries of the Yangtze River in the Three Gorges Reservoir Region. Sci Total Environ 574:1472-1476

33. Spencer RGM, Butler KD, Aiken GR (2012) Dissolved organic carbon and chromophoric dissolved organic matter properties of rivers in the USA. J Geophys Res-Biogeosci 117:G03001

34. Zhu TB, Duan PF, He JG, Zhao MM, Li M (2017) Sources, composition, and spectroscopic characteristics of dissolved organic matter extracted from sediments in an anthropogenic-impacted river in Southeastern China. Environ Sci Pollut Res 24:25431-25440

35. Chen Z, Schmidt B, Schaeffer A (2017) Uptake and decomposition of the herbicide propanil in the plant Bidens pilosa L. dominating in the Yangtze three gorges reservoir (TGR), China. Environ Sci Pollut Res 24:11141-11153

36. Johnson MS, Couto EG, Abdo M, Lehmann J (2011) Fluorescence index as an indicator of dissolved organic carbon quality in hydrologic flowpaths of forested tropical watersheds. Biogeochemistry 105:149-157

37. Mao R, Li S (2019) Temporal controls on dissolved organic carbon biodegradation in subtropical rivers: initial chemical composition versus stoichiometry. Sci Total Environ 651:3064-3069

38. Wang X, Zhang F, Kung H-t, Ghulam A, Trumbo AL, Yang J, Ren Y, Jing $Y$ (2017) Evaluation and estimation of surface water quality in an arid region based on EEM-PARAFAC and 3D fluorescence spectral index: a case study of the Ebinur Lake watershed, China. Catena. 155:62-74

39. Ohno T (2002) Fluorescence inner-filtering correction for determining the humification index of dissolved organic matter. Environ Sci Technol 36:742-746

40. Larouche JR, Abbott BW, Bowden WB, Jones JB (2015) The role of watershed characteristics, permafrost thaw, and wildfire on dissolved organic carbon biodegradability and water chemistry in Arctic headwater streams. Biogeosciences 12:4221-4233

41. Zhang D, Trzcinski AP, Kunacheva C, Stuckey DC, Liu Y, Tan SK, Ng WJ (2016) Characterization of soluble microbial products (SMPs) in a membrane bioreactor (MBR) treating synthetic wastewater containing pharmaceutical compounds. Water Res 102:594-606

42. Vymazal J, Kropfelova L, Wastewater treatment in constructed wetlands with horizontal sub-surface flow. In: Environmental pollution. (2008): Springer, Netherlands. p 566

43. Shen Q, Wang KY, Zhang W, Zhang SC, Wang XJ (2009) Characterization and sources of PAHs in an urban river system in Beijing, China. Environ Geochem Health 31:453-462

44. Zhao S, Jia H, Nulaji G, Gao H, Wang F, Wang C (2017) Photolysis of polycyclic aromatic hydrocarbons (PAHs) on $\mathrm{Fe}^{3+}$-montmorillonite surface under visible light: degradation kinetics, mechanism, and toxicity assessments. Chemosphere 184:1346-1354

45. Sun Y, Dong D, Zhang L, He S, Hua X, Guo Z (2018) Polycyclic aromatic hydrocarbons (PAHs) in an urban river at mid and high latitudes: a case study in Siping, a traditional industrial city in Northeast China. J Environ Sci Health A 53:960-967

46. Zhang Y, Liu S, Song X, Ge H (2008) Prediction for the mixture toxicity of six organophosphorus pesticides to the luminescent bacterium Q67. Ecotoxicol Environ Saf 71:880-888

47. Schäfer RB, Liess M, Altenburger R, Filser J, Hollert H, Roß-Nickoll M, Schäffer A, Scheringer M (2019) Future pesticide risk assessment: narrowing the gap between intention and reality. Environ Sci Eur 31(1):21

48. Derrien M, Lee YK, Shin K-H, Hur J (2018) Comparing discrimination capabilities of fluorescence spectroscopy versus FT-ICR-MS for sources and hydrophobicity of sediment organic matter. Environ Sci Pollut Res 25:1892-1902

49. Brack W, Ait-Aissa S, Altenburger R, Cousins I, Dulio V, Escher B, Focks A, Ginebreda A, Hering D, Hilscherova K, Hollender J, Hollert H, Kortenkamp A, de Alda ML, Posthuma L, Schymanski E, Segner H, Slobodnik J (2019) Let us empower the WFD to prevent risks of chemical pollution in European rivers and lakes. Envrion Sci Eur 31(1):47

\section{Publisher's Note}

Springer Nature remains neutral with regard to jurisdictional claims in published maps and institutional affiliations.

\section{Submit your manuscript to a SpringerOpen ${ }^{\odot}$ journal and benefit from:}

- Convenient online submission

- Rigorous peer review

- Open access: articles freely available online

- High visibility within the field

- Retaining the copyright to your article

Submit your next manuscript at springeropen.com 